\title{
Chemical, physical, microbiological and sensory analyzes of fillets of hybrid sorubins
}

\author{
Análises química, física, microbiológica e sensorial de filés de sorubins híbridos \\ Análisis químicos, físicos, microbiológicos y sensoriales de filetes de sorubins híbridos
}

Received: 06/26/2021 | Reviewed: 07/04/2021 | Accept: 08/19/2021 | Published: 08/22/2021

Angela Dulce Cavenaghi Altemio

ORCID: https://orcid.org/0000-0002-3000-8869

Federal University of Grande Dourados, Brazil E-mail: angelaaltemio@ufgd.edu.br

Aline Silva Lima

ORCID: https://orcid.org/0000-0001-6373-0906 Federal University of Grande Dourados, Brazil E-mail: asl.ufgd@gmail.com

Jully Medeiros de Azevedo

ORCID: https://orcid.org/0000-0001-9275-5731 Federal University of Grande Dourados, Brazil E-mail: jma.ufgd@gmail.com

Thomas Manzato Francisco

ORCID: https://orcid.org/0000-0002-6024-3309 Federal University of Grande Dourados, Brazil E-mail: tmf.ufgd@gmail.com

Gustavo Graciano Fonseca

ORCID: https://orcid.org/0000-0002-8784-661X

Federal University of Grande Dourados, Brazil E-mail: ggf@ufgd.edu.br

\begin{abstract}
Sorubim fillets are products with great commercial potential that meet the current preferences for fish consumption. Hybrids of these species have gaining popularity for industrial fish farming. The aim of this work was to characterize fillets obtained from the crosses between Pseudoplatystoma corruscans and Pseudoplatystoma reticulatum (dot and comma hybrid sorubim) and the crosses between Pseudoplatystoma spp. x Leiarius marmoratus (real hybrid sorubim) in terms of physical, chemical, microbiological, and sensory analyzes. The fillets of real hybrid sorubim presented high moisture (77.90\%) and protein (17.20\%) and low lipid (3.20\%) contents compared to the dot and comma hybrid sorubim $(75.66,21.36$, and $1.90 \%$, respectively). The variation in the constitution of the real hybrid sorubim had affected other parameters, e.g. it increased the texture evaluated in terms of shear strength $(0.58 \mathrm{kgf}$, against $0.46 \mathrm{kgf}$ for the dot and comma hybrid sorubim fillet), and the reduced sensory acceptation / purchase intention, which are related to the reduced fat content. Purchase intention analysis indicated that the filets of dot and comma hybrid sorubim would be purchased by $95 \%$ of the population, while the fillets of the real hybrid sorubim would be purchased for less than $80 \%$ of the population.
\end{abstract}

Keywords: Proximate composition; Colour; Texture; Acceptation.

\section{Resumo}

Os filés de sorubins são produtos com grande potencial comercial que atendem às preferências atuais de consumo de pescado. Os híbridos dessas espécies estão ganhando popularidade na piscicultura industrial. O objetivo deste trabalho foi caracterizar os filés obtidos a partir dos cruzamentos entre Pseudoplatystoma corruscans e Pseudoplatystoma reticulatum (sorubim híbrido ponto e vírgula) e os cruzamentos entre Pseudoplatystoma spp. x Leiarius marmoratus (híbrido de sorubim real) em termos de análises físicas, químicas, microbiológicas e sensoriais. Os filés de sorubim híbrido real apresentaram alto teor de umidade $(77,90 \%)$ e proteína $(17,20 \%)$ e baixo teor de lipídios $(3,20 \%)$ em relação ao sorubim híbrido ponto e vírgula $(75,66,21,36$ e 1,90\%, respectivamente). A variação na constituição do sorubim híbrido real afetou outros parâmetros, por exemplo aumentou a textura avaliada em termos de resistência ao cisalhamento $(0,58 \mathrm{kgf}$, contra $0,46 \mathrm{kgf}$ para o filé de sorubim híbrido ponto e vírgula) e a redução da aceitação sensorial / intenção de compra, que estão relacionados ao reduzido teor de gordura. A análise da intenção de compra indicou que os filés de sorubim híbrido ponto e vírgula seriam comprados por $95 \%$ da população, enquanto os filés de sorubim híbrido real seriam comprados por menos de $80 \%$ da população.

Palavras-chave: Composição proximal; Cor; Textura; Aceitação.

\section{Resumen}

Los filetes de sorubim son productos con gran potencial comercial que responden a las preferencias actuales de consumo de pescado. Los híbridos de estas especies están ganando popularidad en la piscicultura industrial. El 
objetivo de este trabajo fue caracterizar los filetes obtenidos de los cruces entre Pseudoplatystoma corruscans y Pseudoplatystoma reticulatum (sorubim híbrido punto y coma) y los cruces entre Pseudoplatystoma spp. $\mathrm{x}$ Leiarius marmoratus (sorubim híbrido real) en términos de análisis físicos, químicos, microbiológicos y sensoriales. Los filetes de sorubim híbrido real presentaron alto contenido de humedad $(77,90 \%)$ y proteína $(17,20 \%)$ y bajo contenido de lípidos (3,20\%) en comparación con el sorubim híbrido punto y coma (75,66, 21,36 y 1,90\%, respectivamente). La variación en la constitución del sorubim híbrido real había afectado otros parámetros, por ejemplo aumentó la textura evaluada en términos de resistencia al cizallamiento $(0,58 \mathrm{kgf}$, contra $0,46 \mathrm{kgf}$ para el filete de sorubim híbrido punto y coma), y la menor aceptación sensorial / intención de compra, que están relacionadas con la reducción del contenido de grasa. El análisis de intención de compra indicó que los filetes de sorubim híbrido punto y coma serían comprados por $95 \%$ de la población, mientras que los filetes del sorubim híbrido real serían comprados por menos del $80 \%$ de la población.

Palabras clave: Composición aproxima; Color; Textura; Aceptación.

\section{Introduction}

Fish is a food of excellent nutritional value due to its proteins of high biological value, vitamins and microbiological unsaturated fatty acids. The nutritional value and prices of fish depend on the texture of the meat, the chemical composition, the sensory quality, the yield and factors related to the methods of capture and processing (Menegazzo et al., 2016; Abraha et al., 2018; Souza et al., 2020).

The sorubins are species that belongs to the genus Pseudoplatystoma. The hybrids fishes generated by crosses between Pseudoplatystoma corruscans and Pseudoplatystoma reticulatum, popularly known as "dot and comma sorubim" or the crosses between Pseudoplatystoma spp. x Leiarius marmoratus, namely "real sorubim" are among the most commonly cultivated by several producers because they exhibit better growth performance than the pure species (Crepaldi et al. 2006; Cavenaghi-Altemio et al., 2021). They are also recognized by their sensory and market characteristics that are quite attractive for industrial fish farming. The flesh of the surubim is light in color, firm in texture, with little sharp flavor, with a low fat content and absence of intramuscular spines. Considered a noble product, it is suitable for the most varied uses and preparations. These characteristics meet the current and future preferences of the fish flesh market that make the surubim a product with great commercial potential (Hisano et al., 2013; Silva et al., 2018).

The knowledge of the chemical composition of fish is of fundamental importance for the standardization of food products based on nutritional criteria. Numerous factors can influence the chemical composition of fish, some of which are intrinsic in nature, such as genetic, morphological (size and shape) and physiological factors (migration and gonadal development). Exogenous factors, such as climate, season, abundance and type of food, can also affect body composition (Abraha et al., 2018). For the farmed fishes, it is more related and depend on the composition of their diet, which must contain a mixture of ingredients that meets the nutrient requirements necessary for their growth (Hua et al., 2019).

Water holding capacity, texture and colour of the raw materials are also important parameters in fish flesh quality for the development of food products. The water holding capacity (WHC) is one of the most important quality parameters in fish. It is directly related to the extent of protein denaturation, causing changes in the color and tenderness of the flesh. From the point of view of the industry, a low WHC results from a deficient processing and means economic losses due to excessive dripping during storage, transportation and commercialization (Chan et al., 2021). The structural diversity of the connective tissue of the fish species can be determined in terms of texture by the shear strength, which is widely used as an index of flesh firmness (Cheng et al. 2013). The colour is one of the main aspects evaluated by consumers and the instrumental color measurement methods are of great importance for the quality control in the food industry (Pathare et al., 2012).

Thus, the aim of this work was to characterize hybrid sorubim fillets in terms of physical, chemical, microbiological, and sensory analyzes. 


\section{Methodology}

\section{Fillets of hybrid sorubim}

Dot and comma hybrid sorubim (Pseudoplatystoma reticulatum x Pseudoplatystoma corruscans) and real hybrid sorubim (Pseudoplatystoma spp. x Leiarius marmoratus) fishes were obtained from a local fish farm. They were transported live to the Laboratory of Food Technology from the Federal University of Grande Dourados, Dourados, MS, Brazil, where they were stunned by thermonarcosis in a mixture of ice and water (1:1), slaughtered, gutted, washed with 5 ppm chlorinated water spray, and filleted, under refrigerated conditions $\left(12^{\circ} \mathrm{C}\right)$. Fillets were immediately utilized for the analytical determinations, except for the sensory analysis. For this later, fillets were packaged in sterilized 5-layer nylon propylene bags and stored up to one week under freezing prior the analyses.

\section{Proximate composition}

Moisture, crude protein, and crude ash contents of the fish fillets were determined in triplicate according to the methods described by AOAC (2012). Moisture was determined by the oven drying method at $105^{\circ} \mathrm{C}$ until constant weight (method 950.46), protein by the Kjeldhal method (method 928.08), lipids by the hexane extraction technique using a Soxhlet apparatus (method 960.39), and ash by using the muffle oven technique (method 920.153).

\section{Water holding capacity (WHC)}

For the analysis, fillet samples of $2 \mathrm{~g}$ were placed on a filter paper and then between two glass plates. The value obtained by the difference between the sample weights before and after being subjected to $2.5 \mathrm{~kg}$ pressure through a PVC tube, filled internally with sand for $5 \mathrm{~min}$., was expressed as the percentage of retained water in relation to the initial weight of the sample (Cañeque \& Sañudo, 2000).

$W H C=\frac{\text { Before centrifuge weight }- \text { After centrifuge weight }}{\text { Before centrifuge weight }} \times 100$

\section{Cooking loss $(C L)$}

Experiments were carried out in an electric oven pre-heated at $163^{\circ} \mathrm{C}$. Five grams of each sample were weighted and placed into an individual tray inside the oven, where the internal temperature was monitored with the aid of a digital thermometer until reach above $71^{\circ} \mathrm{C}$ in their geometric center. Samples were then removed from the oven and weighted again when the internal temperature of the samples reached $25^{\circ} \mathrm{C}$. The $\mathrm{CL}$ was obtained by taking the difference between the initial and final weight of the fillets, according to the Eq. 2. Determinations were carried out in triplicate and the results were expressed as the percentage of weight loss (AMSA, 2015).

$C L=\frac{\text { Initial mass }- \text { Final mass }}{\text { Initial mass }} \times 100$

\section{Shear strength}

Texture analysis of the fillets was carried out using a texture analyzer Model TAXTplus (Stable Micro Systems, Surrey, England) calibrated with a standard weight of $5 \mathrm{~kg}$. Products kept at $2^{\circ} \mathrm{C}$ were equilibrated at room temperature (28$30^{\circ} \mathrm{C}$ ) before analysis. Slices of $1.3 \mathrm{~cm}$ were cut in the longitudinal direction of the muscle fibers, placed in the texture analyzer and submitted to a cutting/shearing test (speed of $1.0 \mathrm{~mm} / \mathrm{s}$, distance of $30 \mathrm{~mm}$ ) using a Warner-Bratzler shear blade 
( $1 \mathrm{~mm}$ thick) to determine the shear strength, which indicated the firmness of the sample. A minimum of 10 replicates of each treatment were analyzed (Kang \& Chen 2015).

\section{Instrumental colour}

The lightness (L) of the fish fillets (raw and cooked) was evaluated using a colorimeter (Minolta Chroma Meter CR 410), with measurements standardized with respect to the white calibration plate (Jiménez \& Gutiérrez, 2001). Five readings were made from the samples.

\section{Microbiological analysis}

Microbiological analyses of the raw materials and ready-made dishes were performed for thermo-tolerant coliforms at $45^{\circ} \mathrm{C}$, Staphylococcus sp. and Salmonella sp. in accordance with the methodology described elsewhere (USDA/FSIS, 1998).

\section{Sensory analysis}

Sensory analyses of the ready-made dishes were conducted by 50 trained panelists with ages varying from 18 to 40 years old. A structured nine-point hedonic scale (9=like extremely; 1=dislike extremely) was used for evaluation of the attributes taste, odor, colour, and texture. The treatments were heated in microwaves until the internal temperature reached above $71^{\circ} \mathrm{C}$, then they were cut into cubes of edges $2,0 \times 2,0 \times 1,0 \mathrm{~cm}$ and served in disposable containers kept warm for no longer than 15 min., coded with three-digit random numbers. Overall acceptation was evaluated in terms of purchase intention using a 5-point scale, where $5=$ certainly would purchase, $4=$ probably would purchase, $3=$ perhaps would purchase $/$ perhaps would not purchase, 2 = probably would not purchase and $1=$ certainly would not purchase, which was expressed as the percentage of total score (Cavenaghi-Altemio et al., 2018). Purchase intention was analyzed as a percentage and by the minimum Chi-squared value. The acceptation index (AI) was calculated according to Eq. 3. The sample was considered accepted if the value was greater than $70 \%$ (Stone \& Sidel, 1993).

$A I=\frac{\text { Average of attributed grades }}{\text { Maximum attributed grade }} \times 100$

\section{Results and Discussion}

The proximate compositions of the fillets of the dot and comma hybrid sorubim (Pseudoplatystoma reticulatum $\mathrm{x}$ Pseudoplatystoma corruscans) and the real hybrid sorubim (Pseudoplatystoma spp. x Leiarius marmoratus) are shown in Table 1. Results indicate that there was significant difference between any all the parameters of the proximal composition, except for the ash content (Table 1).

Table 1. Proximate composition of the fillets of the dot and comma hybrid sorubim and the real hybrid sorubim.

\begin{tabular}{ccccc}
\hline Hybrid sorubim & Moisture (\%) & Protein (\%) & Lipids (\%) & Ash (\%) \\
\hline Dot and comma & $77.90 \pm 0.54^{\mathrm{a}}$ & $17.20 \pm 0.42^{\mathrm{b}}$ & $3.20 \pm 0.12^{\mathrm{a}}$ & $1.65 \pm 0.35^{\mathrm{a}}$ \\
Real & $75.66 \pm 0.64^{\mathrm{b}}$ & $21.36 \pm 0.39^{\mathrm{a}}$ & $1.90 \pm 0.09^{\mathrm{b}}$ & $1.05 \pm 0.30^{\mathrm{a}}$ \\
\hline
\end{tabular}

Means with the same letter in the same column do not differ statistically at $5 \%$ (p>0.05). Source: Authors.

The obtained results are also in good agreement with the literature for fillets of, e.g. Pseudoplatystoma corruscans (74.06\% moisture, $19.28 \%$ proteins, 4.85\% lipids, 1.22\% ash) (Frascá-Scorvo et al., 2008) / (77.26\% moisture, 17.90\% 
proteins, 3.30\% lipids, $1.01 \%$ ash) (Ramos Filho et al., 2008), Pseudoplatystoma fascinatum (70.58\% moisture, 18.50\% proteins, 10.03\% lipids, 0.76\% ash) (Ramos Filho et al., 2008), Pseudoplatystoma sp. (64.83\% moisture, 20.63\% proteins, $1.64 \%$ lipids, $1.81 \%$ ash) (Burkert et al., 2008), Leiarius marmoratus (74.71\% moisture, 17.69\% proteins, $4.86 \%$ lipids, $1.03 \%$ ash) (Souza et al., 2020). The higher protein content (21.36\%) obtained for the real hybrid sorubim compared to the dot and comma hybrid sorubim and the other species reported is underlined (Table 1). As these fishes were raised in captivity, fed basically with commercial feed, it is probable that differences may be related mainly to genetic factors.

The average water holding capacity $(\mathrm{WHC})$ differed $(\mathrm{p}<0.05)$ between fillets. The obtained values were $48.17 \%$ for the fillets of the dot and comma hybrid sorubim and $57.88 \%$ for the fillets of real hybrid sorubim (Table 2). Literature reports ranges from 53.94 to $62.53 \%$ to fillets of captured Pseudoplatystoma corruscans (Lara et al., 2010), 59.95 to 63.59\% of WHC for fillets of farmed Pseudoplatystoma spp. (Fantini et al., 2015, 2020), and proximately 68\% for fillets of Pseudoplatystoma sp. obtained from the commerce (Honorato et al., 2014). Different protein contents and isoelectric points may explain these differences. However, no significant difference ( $\mathrm{p}>0.05)$ was found for the cooking losses. The obtained values were $23.78 \%$ for the fillets of the dot and comma hybrid sorubim and $24.15 \%$ for the fillets of real hybrid sorubim (Table 2). The literature reports an average of $24.5 \%$ of cooking losses for fillets of Pseudoplatystoma sp. (Honorato et al., 2014).

Table 2. Water holding capacity (WHC), cooking loss, shear strength and lightness (L) of the fillets of the dot and comma hybrid sorubim and the real hybrid sorubim.

\begin{tabular}{ccc}
\hline \multirow{2}{*}{ Physical determinations } & \multicolumn{2}{c}{ Hybrid sorubim fillet } \\
\cline { 2 - 3 } & Dot and comma & Real \\
\hline WHC (\%) & $48.17 \pm 0.04^{\mathrm{b}}$ & $57.88 \pm 0.03^{\mathrm{a}}$ \\
Cooking loss (\%) & $23.78 \pm 0.85^{\mathrm{a}}$ & $24.15 \pm 0.91^{\mathrm{a}}$ \\
Shear strength (kgf) & $0.58 \pm 0.07^{\mathrm{a}}$ & $0.46 \pm 0.08^{\mathrm{a}}$ \\
Lraw fillet & $60.79 \pm 0.57^{\mathrm{a}}$ & $62.58 \pm 0.65^{\mathrm{a}}$ \\
Lcooked fillet & $77.35 \pm 0.37^{\mathrm{a}}$ & $76.65 \pm 0.52^{\mathrm{a}}$ \\
\hline
\end{tabular}

Means with the same letter in the same line do not differ statistically at 5\% (p>0.05). Source: Authors.

The shear strength did not present a significant difference $(\mathrm{p}>0.05)$ between the dot and comma hybrid sorubim $(0.58$ kgf) and the real hybrid sorubim (0.46 kgf) (Table 2). These values were lower than the results reported elsewhere for fillets of farmed Pseudoplatystoma spp. (0.78 - $1.06 \mathrm{kgf}$ ) (Fantini et al., 2015) and fillets of Pseudoplatystoma sp. obtained from the commerce (0.66 kgf) (Honorato et al., 2014).

The lightness (L) (L) did not present a significant difference ( $>0.05)$ between the dot and comma hybrid sorubim (60.79) and the real hybrid sorubim (62.58) (Table 2). These values were superior to those reported for fillets of farmed Pseudoplatystoma spp. (48.73 - 49.09) (Fantini et al., 2015) and close to those showed for fillets of Pseudoplatystoma sp. obtained from the commerce (60.0). After cooking, the fillets still did not significantly differ ( $p>0.05)$ for the parameters L. However, cooking increased the luminosity of both fillets (Table 2).

The results of the microbiological analyzes carried out for the fillets of the dot and comma hybrid sorubim and the real hybrid sorubim were found within the established by Brazilian legislation, which establishes an absence of absence of Salmonella sp. in $25 \mathrm{~g}$, and maximum counts of $5 \times 10^{2} \mathrm{UFC} / \mathrm{g}$ for $\mathrm{S}$. aureus, and of $1 \times 10^{3} \mathrm{UFC} / \mathrm{g}$ for thermotolerant coliforms at $45^{\circ} \mathrm{C}$ (ANVISA, 2001). Thus, the hygienic-sanitary procedures were considered adequate and the fillets safe for the sensory analysis. 
Table 3 shows the means and standard deviations of the scores of the sensory attributes (taste, odor, color, and texture) for the consumer acceptance test of the hybrid sorubim fillets. The average classification for all sensory attributes ranged varied from "I liked it moderately" to "I liked it a lot" (Table 3). There was a significant difference only for the sensory attributes taste and texture between the fillets of the dot and comma hybrid sorubim and the real hybrid sorubim. The highest average scores were 8.2 and 8.1 (I liked it a lot) for the attributes taste and texture, respectively, obtained for the fillets of the dot and comma hybrid sorubim (Table 3). This greater acceptance may be related to the highest moisture, and lipid contents obtained for this fish fillet (Table 1), which improve the juiciness and softness of the fillet. All treatments presented acceptability indexes above $80.3 \%$ (Table 3, in parenthesis). When the acceptability index is equal to or greater than $70 \%$, the product is considered accepted (Stone \& Sidel 2004). Thus, all hybrid sorubim fillets were accepted in relation to all sensory attributes evaluated.

Table 3. Sensory analysis of the fillets of the dot and comma hybrid sorubim and the real hybrid sorubim.

\begin{tabular}{ccccc}
\hline Hybrid sorubim & Taste & Odor & Color & Texture \\
\hline Dot and comma & $8.20^{\mathrm{a}} \pm 0.59(91.1)$ & $7.23^{\mathrm{a}} \pm 0.55(80.3)$ & $7.67^{\mathrm{a}} \pm 0.59(85.2)$ & $8.10^{\mathrm{a}} \pm 0.48(90.0)$ \\
Real & $7.53^{\mathrm{b}} \pm 0.56(83.7)$ & $7.43^{\mathrm{a}} \pm 0.52(82.5)$ & $7.60^{\mathrm{a}} \pm 0.50(84.4)$ & $7.53^{\mathrm{b}} \pm 0.52(83.7)$ \\
\hline
\end{tabular}

Means with the same letter in the same column do not differ statistically at 5\% (p>0.05). Values in parenthesis are referred to the acceptation index $(\%)$. Source: Authors.

Figure 1 shows the percentage of the purchase intention frequencies of the fish fillets. Fillets of the dot and comma hybrid sorubim had the highest percentage of purchase intention (86.67\%) for the sum "certainly would buy" and "probably buy". The fillets of the real hybrid sorubim also presented a high purchase intention (83.34\%) according to this criterion. However, if consider only the sum of grades for "certainly would buy", the fillets of the dot and comma hybrid sorubim were much more accepted. Moreover, using the critical chi-square values, at 5\% significance, the filets of dot and comma hybrid sorubim would be purchased by $95 \%$ of the population, while the fillets of the real hybrid sorubim would be purchased for less than $80 \%$ of the population.

Figure 1. Purchase intention (\%) of the fillets of the dot and comma hybrid sorubim and the real hybrid sorubim.

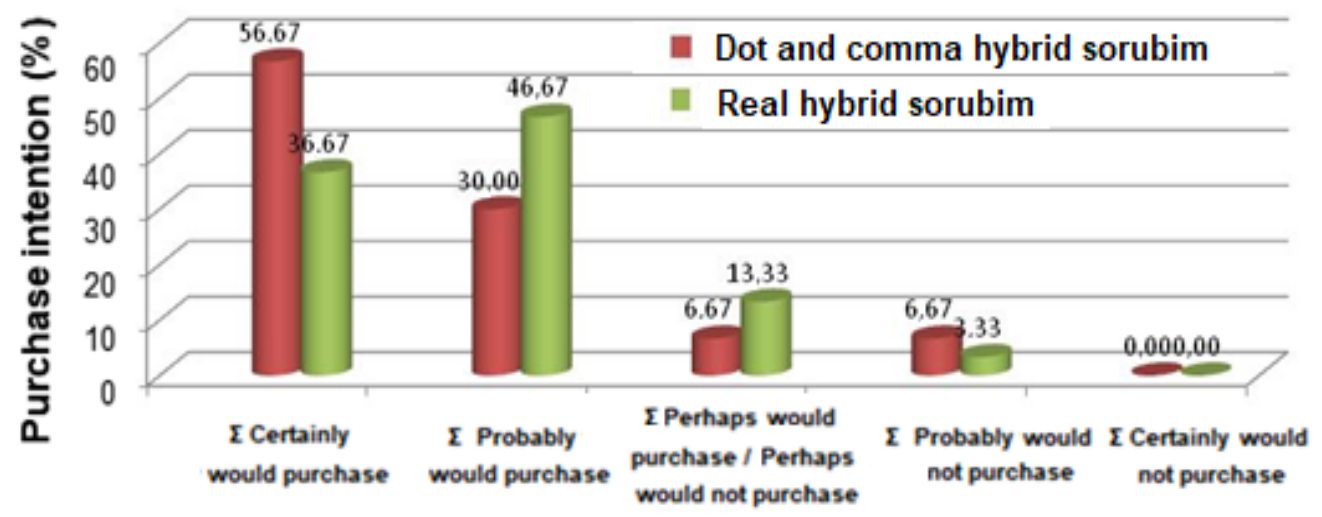

Source: Authors. 


\section{Conclusion}

The fillets of real hybrid sorubim presented high moisture and protein and low lipid contents compared to the dot and comma hybrid sorubim and other related species. Despite the real hybrid sorubim have been developed with this main purpose (reduced fat), it became evident that this variation in the constitution of the fish had affected other parameters, e.g. the increased texture evaluated in terms of shear strength, and the reduced sensory acceptation / purchase intention, which are related to the reduced fat content. We suggest studies on the development on innovative novel food products based on both real and dot and comma hybrid sorubins' meats.

\section{Acknowledgments}

The authors gratefully acknowledge the Brazilian research funding agencies CAPES, CNPq and FUNDECT for their financial support.

\section{References}

AMSA. (2015). American Meat Science Association. Research Guidelines for Cookery, Sensory Evaluation, and Instrumental Tenderness Measurements of Meat. Champaign, IL, USA.

ANVISA. (2001). Brazilian National Health Surveillance Agency. Resolution RDC No. 12 of January $2^{\text {nd }}, 2001$.

AOAC. (2012). Official methods of analysis of AOAC International (19 $9^{\text {th }}$ ed.). Gaithersburg, MD, USA, AOAC International.

Burkert, D., Andrade, D. R., Sirol, R. N., Salaro, A. L., Rasguido, J. E. A. \& Quirino, C. R. (2008). Processing yield and chemical composition of fillets of surubim reared in net cages. Revista Brasileira de Zootecnia, 37, 1137-1143.

Cañeque, V. \& Sañudo, C. (2000). Metodología para el Estúdio de la Calidad de la Canal y de la Carne en Rumiantes. Instituto Nacional de Investigación y Tecnología y Alimentaria. Madrid, Spain.

Cavenaghi-Altemio, A. D., Hashinokuti, A. A., Albuquerque, D. M., Fonseca, G. G. (2018). Transglutaminase addition increases quality and acceptation of sausages obtained from mechanically separated meat of hybrid sorubins. Emirates Journal of Food and Agriculture, 30, 952-958.

Cavenaghi, A. D., Lopes, A. B., Missio, M. D. C. \& Fonseca, G. G. (2021). Feasibility of using fillet and mechanically separated meat of hybrid sorubim in inlaid ham type products. Journal of Aquatic Food Product Technology, 30, 76-84.

Chan S. S., Skare, M., Rotabakk, B. T., Sivertsvik, M., Lerfall, J., Løvdal, T. \& Roth, B. (2021). Evaluation of physical and instrumentally determined sensory attributes of Atlantic salmon portions packaged in modified atmosphere and vacuum skin. LWT - Food Science and Technology, 146, 111404.

Cheng, J. -H., Sun, D. -W., Han, Z. \& Zeng, X. -A. (2013). Texture and structure measurements and analyses for evaluation of fish and fillet freshness quality: A review. Comprehensive Reviews in Food Science and Food Safety, 13, 52-61.

Crepaldi, D. V., Faria, P. M. C., Teixeira, E. A., Ribeiro, L. P., Costa, Â. A. P., de Melo, D. C., Cintra, A. P. R., Prado, S. A., Costa, F. A. A., Drumond, M. L., Lopes, V. E. \& de Moraes V. E. (2006). The Brazilian catfish in Brazil aquaculture. Revista Brasileira de Reprodução Animal, 30, 150-158.

Fantini, L. E., Rodrigues, R. A., Honorato, C. A., Goes, E. S. R., Ferraz, A. L. J., de Lara, J. A. F., Hanson, T. \& de Campos, C. M. (2020). Resting time before slaughter restores homeostasis, increases rigor mortis time and fillet quality of surubim Pseudoplatystoma spp. PLoS One, 15, e0233636.

Fantini, L. E., de Lara, J. A. F., Delbem, Á. C. B., Ushizima, T. T., Povh, J. A. \& de Campos, C. M. (2015). Quality attributes and properties of surubim (Pseudoplatystoma spp.) meat. Semina: Ciências Agrárias, 36, 3957-3964.

Frascá-Scorvo, C. M. D., Baccarin, A. E., Vidotti, R. M., Romagosa, E., Scorvo-Filho, J. D. \& Ayroza, L. M. S. (2008). Influence of stoking densities, intensive and semi-intensive rearing systems on carcass yield, nutritional quality of the fillet and organoleptic characteristics of pintado Pseudoplatystoma corruscans. Boletim do Instituto de Pesca, 34, 511-518.

Hisano, H., Fonseca, G. G., Russo, M. R., Della Flora, M. A. L., Ishikawa, M. M. \& Padua, S. B. (2013). Hybrid sorubim viscera protein concentrate in the diets for barred sorubim. Boletim do Instituto de Pesca, 39, 37-44.

Honorato, C. A., Caneppele, A., Matoso, J. C., Prado, M. R., Siqueira, M. S. \& Souza, L. R. O. (2014). Physical characterization of fillets of surubi (Pseudoplatystoma sp.), pacu (Piaractus mesopotamicus) and pirarucu (Arapaimas gigas). Arquivos de Ciências Veterinárias e Zoologia, 17, $237-242$.

Hua K., Cobcroft, J. M., Cole, A., Condon, K., Jerry, D. R., Mangott, A., Praeger, C., Vucko, M. J., Zeng, C., Zenger, K. \& Strugnell, J. M. (2019). The future of aquatic protein: implications for protein sources in aquaculture diets. One Earth, 1, 316-329.

Jiménez, A. \& Gutiérrez, G. C. (2001). Métodos para Medir Propiedades Físicas en Industrias de Alimentos. In: Alvarado, J. D. and Aguilera, J. M., editors. Editorial Acribia S.A., Zaragoza, Spain. 
Research, Society and Development, v. 10, n. 11, e15101117579, 2021

(CC BY 4.0) | ISSN 2525-3409 | DOI: http://dx.doi.org/10.33448/rsd-v10i11.17579

Kang H. -Y. \& Chen H. -H. (2014). Improving the crispness of microwave-reheated fish nuggets by adding chitosan-silica hybrid microcapsules to the batter. LWT - Food Science and Technology, 62, 740-745.

Lara, J. A. F., Gafbelini, J. S. \& Delbem, A. C. D. Determination of water holding capacity in fillets of pintado obtained in the Paraguay river (Corumbá-MS). In: $5^{\circ}$ Simpósio sobre recursos naturais e socioeconômicos do Pantanal, 2010, Corumbá.

Menegazzo, M. L., Petenucci, M. E. \& Fonseca, G. G. (2016). Quality assessment of Nile tilapia and hybrid sorubim oils during storage at low temperature. Food Bioscience, 16, 1-4.

Pathare, P. B., Opara, U. L. \& Al-Said, F. A. -J. (2012). Colour measurement and analysis in fresh and processed foods: A Review. Food and Bioprocess Technology, 6, 36-60.

Ramos Filho, M. M., Ramos, M. I. L., Hiane, P. A. \& Souza, E. M. T. (2008). Lipid profile of four species of fish from the Pantanal region of Mato Grosso do Sul. Food Science and Technology, 28, 361-365.

Silva, R. S., Santos, B. M. M., Pizato, S., Fonseca, G. G. \& Cortez-Vega, W. R. (2018). Evaluation of protein isolate obtained from byproducts of hybrid sorubim (Pseudoplatystoma reticulatum x Pseudoplatystoma corruscans). Journal of Bioenergy and Food Science, 5, 1-11.

Souza A. F. L., Petenuci M. E., Camparim R., Visentainer J. V. \& da Silva A. J. I. (2020). Effect of seasonal variations on fatty acid composition and nutritional profiles of siluriformes fish species from the amazon basin. Food Research International, 132, 109051

Stone, H. S. \& Sidel, J. L. Sensory Evaluation Practices, ( $3^{\text {rd }}$ ed.). Academic Press, San Diego, 2004.

USDA/FSIS. USDA/FSIS Microbiology Laboratory Guidebook. ( $3^{\text {rd }}$ ed.). United States Department of Agriculture. Food Safety and Inspection Service, Washington, DC, 1998. 